\title{
Historical Development of the Present Day Lineaments of the Western Zagros Fold Thrust Belt A Case Study from Northeastern Iraq, Kurdistan Region
}

\author{
Kamal H. Karim \\ Department of Geology \\ College of Science \\ University Sulaimani
}

\author{
Amanj I. Fatagh \\ Department of Geology \\ College of Science \\ University Sulaimani
}

Hemin Koyi

Department of Geology

University of Gotenjen, Sweden

\author{
Azad Ibrahim \\ Department of Geology \\ College of Science \\ University Sulaimani
}

(Received 18/2/2008, Accepted 26/2/2009)

\begin{abstract}
The part of the Zagros within the Iraqi border occupies an area less than quarter of the country. It includes three tectonic zones which can be clearly identified in the field. These are the Low and High Folded, Imbricated and Thrusted Zones. The main lineaments are the axes of the anticlines; transverse and longitudinal faults; lines of distribution of ophiolite and metamorphic rocks; drainage direction discharge and line of distribution of conglomerates. The direction of axes of the anticlines are trending nearly $\mathrm{N} 38 \mathrm{~W}$ which normal to the direction of the imposed stress by the Iranian plate front. Due to differences in thicknesses and physical properties of the sedimentary rocks, the axes of these anticlines are not continuous they plunge more or less in an en echelon pattern and in some cases are bend. The lengths of most of these anticlines are around $10-30 \mathrm{~km}$. The first appearance of the anticlines in the High Folded Zone possibly started at the Eocene while those of the Thrust Zone initiated at Maastrichtian. Some of these anticlines are cut by transverse faults whose ages are not known. These faults trend nearly normal to the axis of anticlines. Other kinds of lineaments are the distribution of ophiolites and metamorphic rocks. Historically the first appearance of trace of ophiolites (as pebbles in sedimentary rocks) has an age of Lower Maastrichtian.

The direction of drainage discharge is nearly towards the south and southwest, which is inherited from that of the Upper Cretaceous and Tertiary paleocurrent directions (sediment transport direction). This direction is related to uplift of the extreme northwestern part of the studied area during Maastrichtian. Evidence for these suggestions is the occurrence of thicknesses of $500 \mathrm{~m}$ of conglomerates as valley fillings during Late Cretaceous. The depositional axes of the successions was migrated for about $50 \mathrm{kms}$ during Cretaceous and Tertiary and becomes younger from northeast towards the southwest as recorded by four narrow belts. The line of migration is nearly coinciding with both directions of present regional slope and the Cretaceous sediment transport.
\end{abstract}




\section{تاريخ تطور التراكيب الخطية الحالية لمنطقة حزام الزاجروس الغربية المطوية والمندفعة دراسة خاصة بإقليم كردستان، شمال شرق العراق}

\author{
ازاد ابراهيم \\ قسم علوم الأرض البران \\ كلية العلوم \\ جامعة السلبيانية
}

\author{
امانتج (براهيم فتاح \\ قسم علوم الأرض أبر \\ كلية العلوم \\ جامعة السلبهانية \\ هيمن كويبي \\ قسم علوم الارض \\ جامعة كوتنجن \\ السوب؛
}

كمال حاجي كريم

قسم علوم الأرض

كلية العلوم

جامعة السليمانية

\section{الملخص}

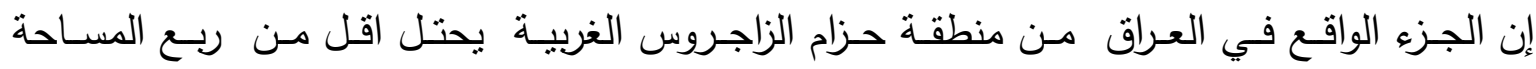
السطحية من البلاد ويتضمن ثلاثة أنطقة تركيبة واضحة المعالم في الحقل. وهذة الانطقة هي نطاق الطيات الواطئة والعالية ونطاق التراكب و نطاق الزحف. ان التراكيب الخطية الرئيسية، في منطقة الدراسة، عبارة عن محاور الطيات والصدوع الطولية والعرضية وخطوط توزيع الاوفيولات والصخور المتحولة واتجاهات تصريف الرسبيات وخطوط توزيع تجمع المدملكات. و تتجه محاور الطيات الحالية حوالي ^ب درجة شمال غرب وتكون عموديـة على اتجاه الضـط النـاتج عن حركة الصفيحة الايرانيـة. وبسبب عدم تجـانس الخواص الطباقية الحركية و الاختلاف في تقدم مقدمة الصفحة الايرانية يظهر عدم استمرارية و التواء في محاور الطيات ويتراوح طول المحاور من · ا الى • ب كم و إن اول ظهور للطيات يرجع ( على الأرجح) الى الايوسين في نطاق الطيات العالية بينما في النطاق الزاحف يرجع الى الماسترختيان المبكر • و بعض الطيات ثتقاطع بواسطة الصدوع العرضية( كالتراكيب الخطية العموديـة على محاور الطيات ) ذات العمر غير المعروف. و النوع الاخر من التراكيب الخطية هي خطوط توزيع الافيولايت و الصخور المتحولة حيث

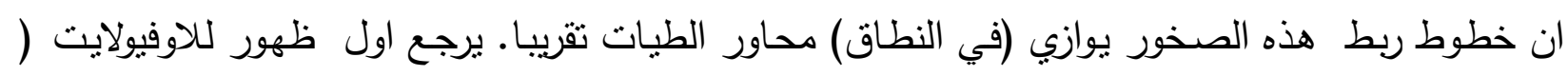
كحصوات في الصخور الرسوبية) الى الماسنرختيان الاسفل. و يتجه مسار تصريف الرسوبيات والمياه الى الجنوب و الجنوب الغربي وهذا الاتجاه موروث من اتجاه التيار القديم و تطور تكتونية الكريتاسي العلوي والعصر الثلاتي حيث بدأ اول جربان جنوبي للرسوبيات في الكريتاسي المتاخر . الدليل على هذا الاتجاه وجود حوالي · . 


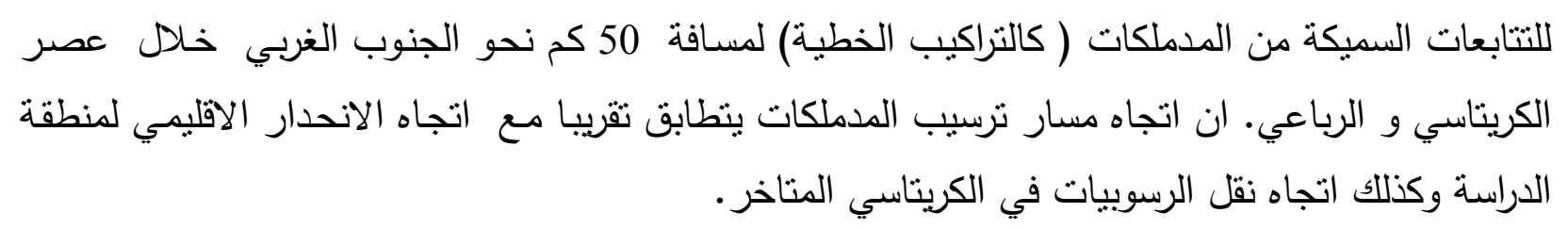

\section{INTRODUCTION}

The present study deals with the Western Zagros Mountain Belt that is located in Iraq and is elongated parallel to Iran-Iraq border (Fig. I and 2). On the regional scale the Western Zagros mountain belt consists of relatively straight and continuous series of high mountains that runs from southeast of Arabian Gulf to the eastern part of Anatolia at the northwest. The series has the elongation trend of northwest-southeast. The tectonic zones (Thrust, Imbricated, High and Low Folded Zones, fig.2) of Buday (1980) and Buday and Jassim (1987) have more or less local disturbances in the directions of elongation. When the ideas of Turrini, et al. (2001), Schreuer, et al. (2001) and Marshak (2004) are considered, these disturbances could be attributed to the difference of mechanical properties of stratigraphic units. According to the same authors, the local difference in the compressional stress of the orogenic wedge (the southwest thrusting of Iranian plate front) and local structures have affected these disturbances (Fig.1 and 2). The field study showed that the belt contains clear large lineaments which have great importance in the studying of the depositional and tectonic history of the area where the sedimentary, igneous and metamorphic rocks and deformational lineaments are all combined mutually with the paleocurrent directions. Therefore the present study deals with the location, types and historical development of these lineaments. In literature, many studies, as a part of a structural geology, have been conducted for lineament analyses (without their historical developments) of the northeastern and northern Iraq such as Omer (2006) and Al-Brifkani(2008).

\section{LINEAMENTS}

Northeastern Iraq which is part of Western Zagros Mountain series shows well developed various large lineaments which could be seen in the field and by aerial photographs and satellite images. These lineaments generally reflect the effect and direction of the thrusting front of Iranian plate which has the general direction of S38W and may have local variations of plus or minus 10 degrees. These lineaments are as follows:

\section{1- Axes of the anticlines}

The main and wide spread lineaments are the axes of the anticlines which have the general direction of Zagros Fold-Thrust Belt (Fig.1). The trends of theses axes are nearly normal to the direction of the imposed stress (S38W). Due to differences in the thicknesses and mechanical stratigraphy of the sedimentary rocks, the axes of these anticlines are not continuous but plunge in an en echelon pattern. This can be seen in Dokan area where Piramagroon, Sara and Kosrat anticlines are arranged in this pattern from southeast to northwest. The same thing is true for the area between Arbat and 
Said Sadiq town where this pattern can be seen to the north of the road where many anticlines plunge under the Sharazoor plain in en echelon pattern. The lengths of most of these anticlines are around $10-30 \mathrm{~km}$. Some of these anticlines are cut by transverse faults.

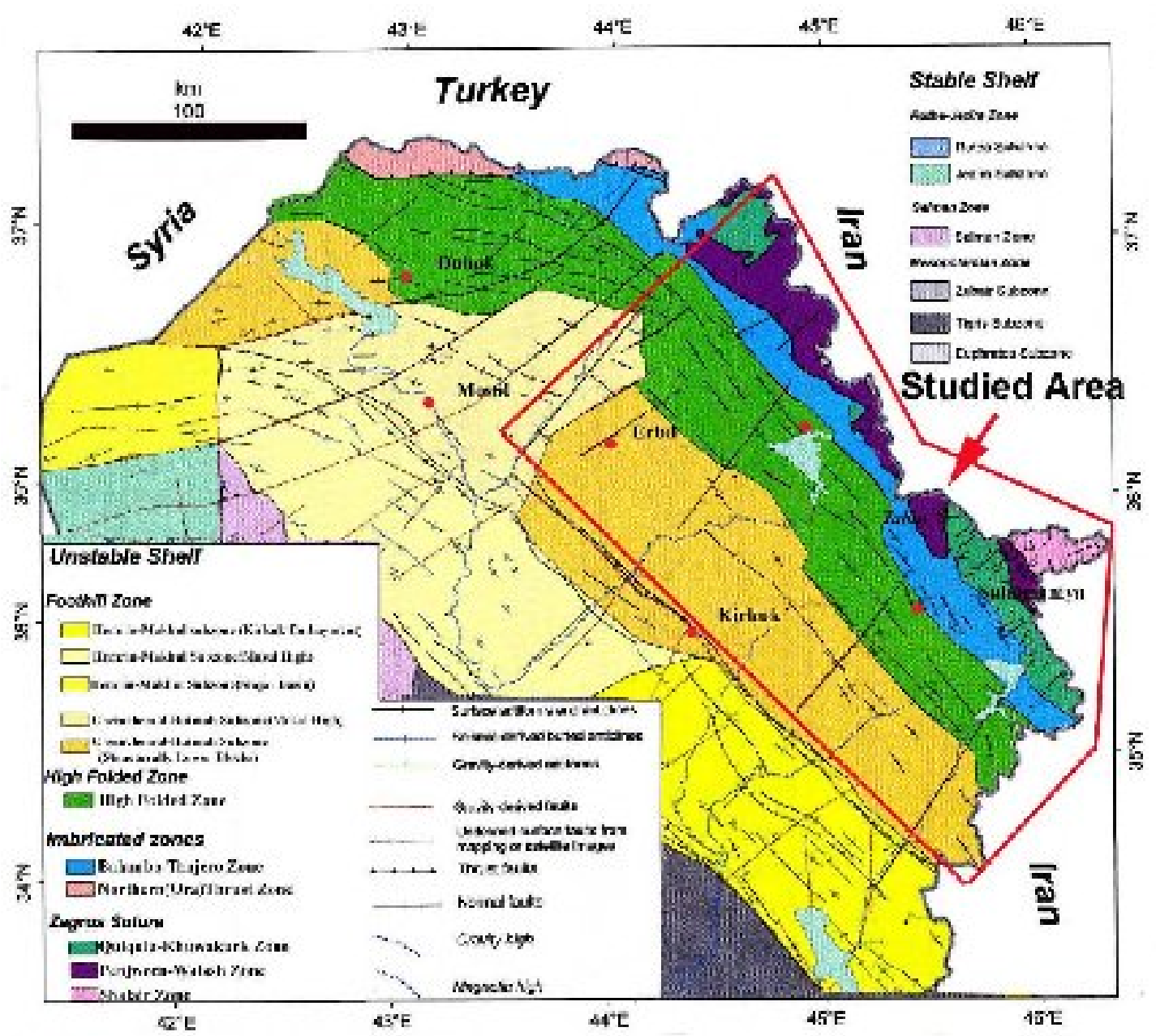

Fig. 1: Tectonic map of Northeastern Iraq (Al-Kadhimi et al, 1996) shows location of some of the prominent lineaments of the studied area.

The historical development of these anticlines is still controversial and is related to the collision of the Iranian and Arabian Plates, and the migration of the tectonic deformation towards the southwest inside Iraq. According to, Buday (1980), Buday and Jassim (1987), Numan (1997, 2000, and 2002) and Al-Qayim (2000) the collision of the continental parts occurred in the Eocene. Recently, Karim, (2004) Karim and Surdashy (2005a and 2005b) inferred from sedimentologically evidences that, the collision of the continental parts occurred in the Campanian. According to these workers the main thrust fault developed at the Campanian and a foreland basin was generated directly to the southwest (Fig.3A and B). 


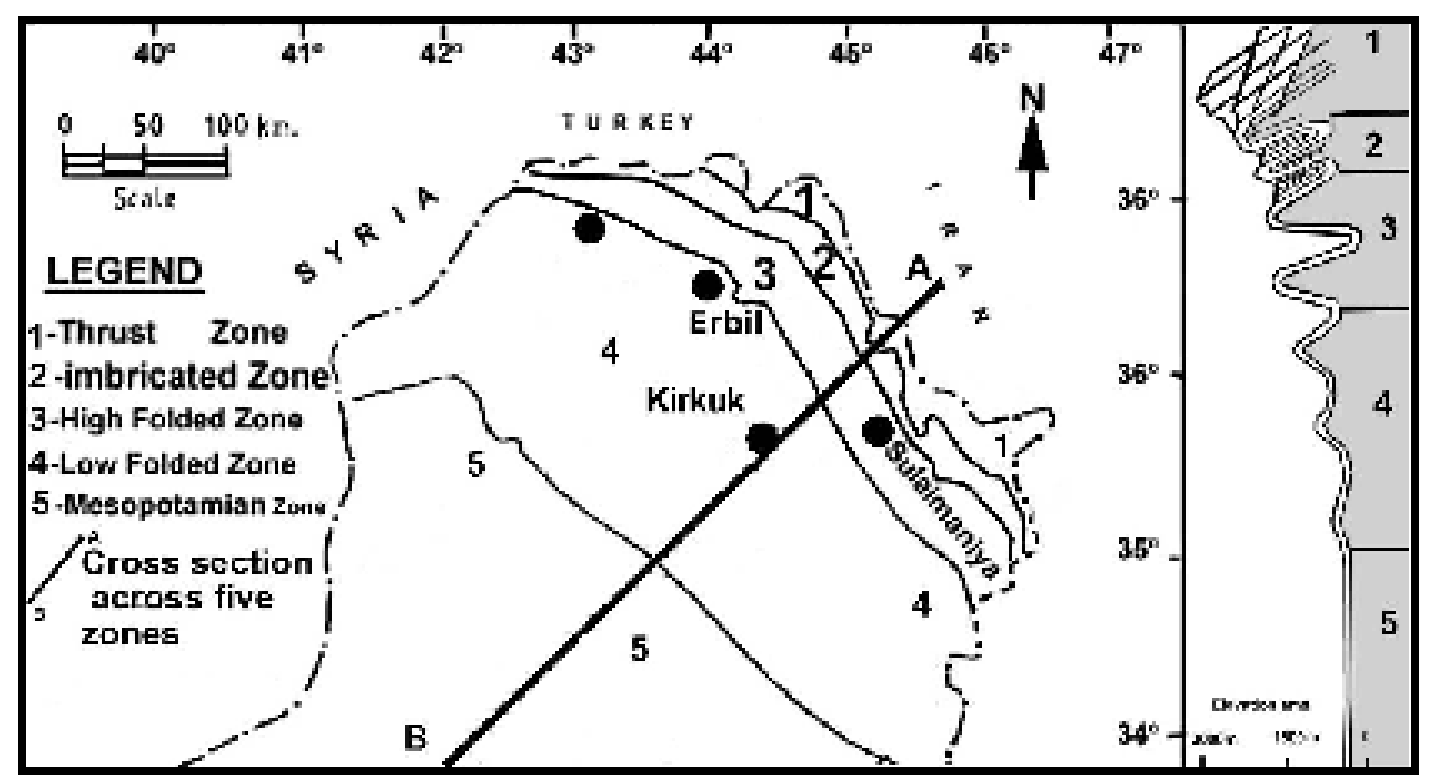

Fig. $r$ : Boundaries of the tectonic subdivision of the Western Zagros in Iraq (modified from Buday and Jassim, 1987).

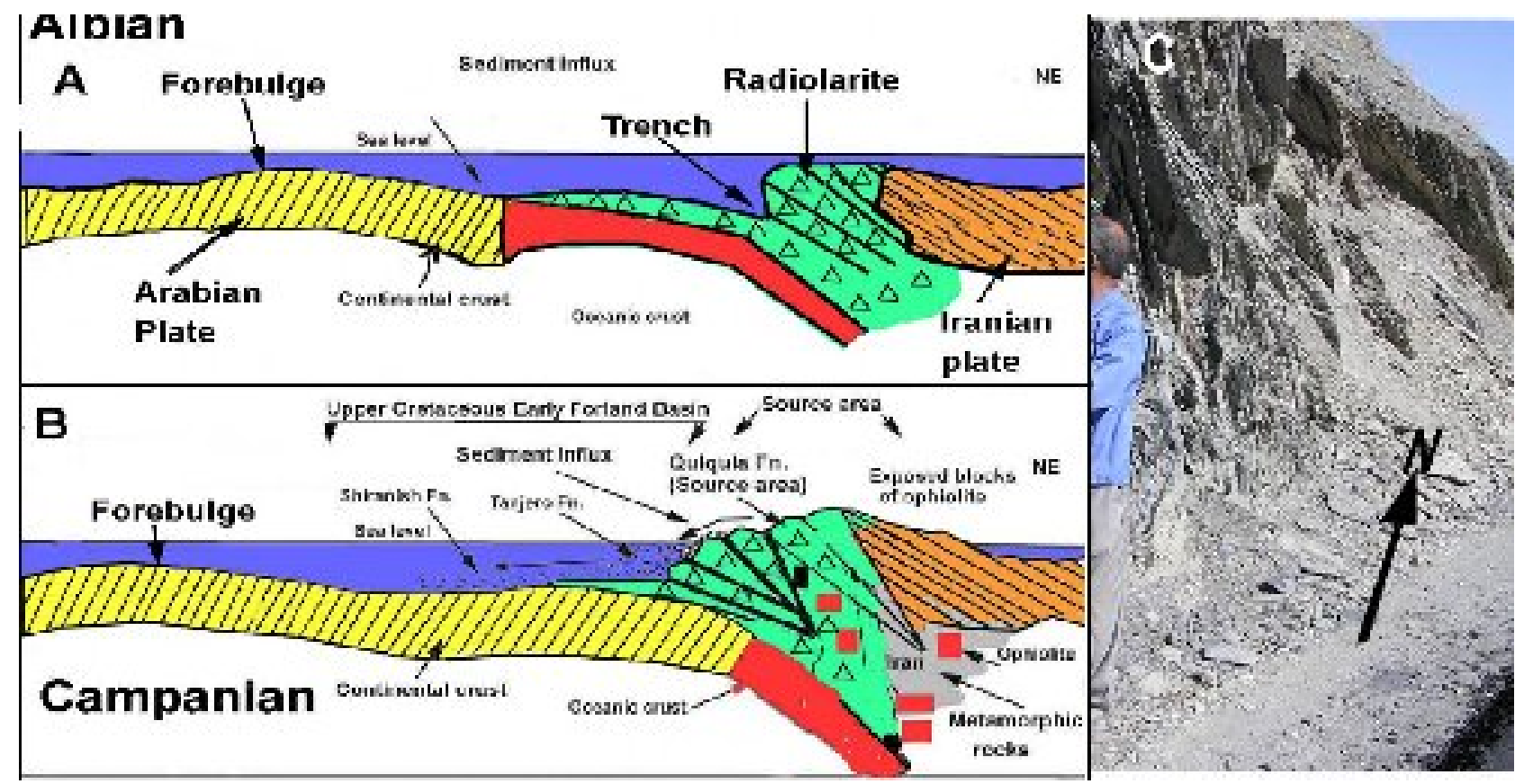

Fig.3: A) Tectonic model of the studied area during early Cretaceous showing accumulation of the radiolarites as accretionary prism and forming foreland forebulge. B) Development of foreland basin and southwestern drainage discharge (sediment transport) by uplift of radiolarites due to collision of Arabian and Iranian plates. C) Shelair phyllite formed by the stress of the two plates. 
Therefore, the first folding, in Iraq, in the present Thrust Zone occurred during the Campanian. Among the anticlines that most possibly related to that time is Avroman Anticline in the Thrust Zone. Later on, the tectonic front migrated towards the foreland interior (towards the southwest) and reached the High Folded Zone during Middle Eocene. A positive land was generated during this age in the present position of the Shinarwe, Goizha, Kewa Rash Mountains in the high Folded Zones (Karim et al, 2008). This positive land, as possible anticlines, separated the early Foreland basin into two minor basins. Towards Late Miocene the tectonic deformation (folding) migrated southwestward and reached the Low Folded Zone (Karim et al, 2008).

\section{2- Distribution of Igneous and Metamorphic rocks}

The igneous rocks, as ophiolite complexes, are distributed along a more or less straight line near the borders with Iran which was studied by Jassim and Al-Hassan (1977) and Buday and Jassim (1987), Aswad et al., (1991), and Aswad (1999). This lineament has the black or dark violet color on satellite images and its direction coincides nearly with the Zagros Suture Zone and the schistosity of metamorphic Rocks (slate, phyllite that are exposed around Garmik and Penjween towns) (Fig.3c) with attitude of $320^{\circ}, 70^{\circ}$ as arranged according to the right hand rule. The distribution of igneous rocks is not continuous but has occurred as separate spots or blocks (Fig.1). Some blocks are dislocated from the straight line; an example of such blocks is the Mawat ophiolite complex which has been thrusted further towards southward than the other blocks. Karim (2005) attributed this dislocation to the existence of graben in the area which acted as privileged direction for thrusting. When these blocks are connected by a line they give clear and large lineament which is nearly parallel to the axes of the anticlines.

\section{3-First appearance of ophiolite}

The age of appearance of this lineament is not exactly known, but Aswad and Elias (1988) stated that it appeared in the Albian-Cenomanian. Karim (2004, 2006b) found gravels and boulders of gabbro and peridotite in the conglomerate of the Tanjero Formation (Fig. 4A). The age of this conglomerate is Early Maastrichtian determined by planktonic foraminiferal zonation of hemiplagite by Abdel Kareem (1986b). Karim (2004) showed that the interbedded marl and sandstone of the distal area is equivalent to the conglomerate at proximal (coastal) area.

The appearance of these clasts is important as it indicates that the emplacement of ophiolite in the suture zone of Zagros Belt started at the Maastrichtian. Another importance of these clasts is the possible indication of dissection of newly uplifted Upper Cretaceous positive land (foreland) by deep valleys causing the emplaced igneous bodies to be exposed to erosion processes. In this connection Karim and Surdashy (2006) found four incised valleys in the sediments of Tanjero Formation during Maastrichtian (Fig. 5B). 


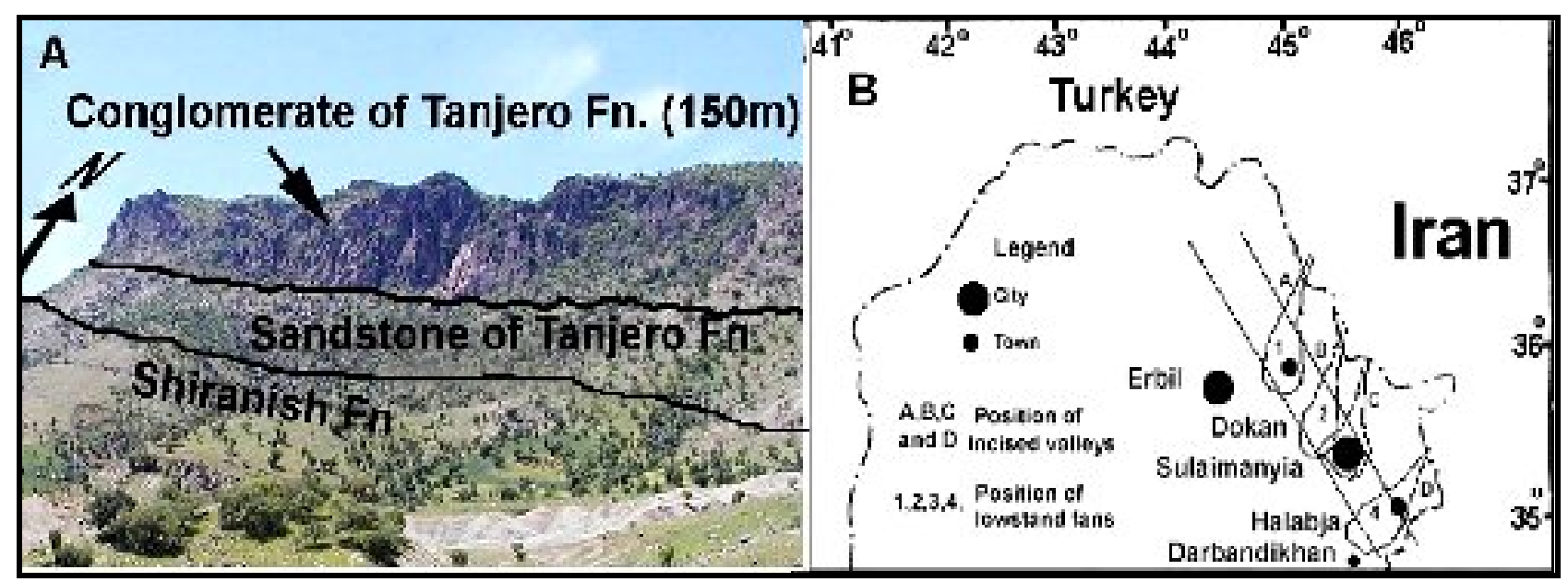

Fig.4: A) Conglomerate bed of Tanjero Formation that contain first appearance of boulders and gavels of Gabbro in history of Iraq, West of Shekhan village, Qandil mountain towards the at east of Kometan village. B) Four ancient valleys (Maastrichtian) that drain the surface runoff of the hinterland into the foreland basin (Modified from Karim and Surdashy, 2006).

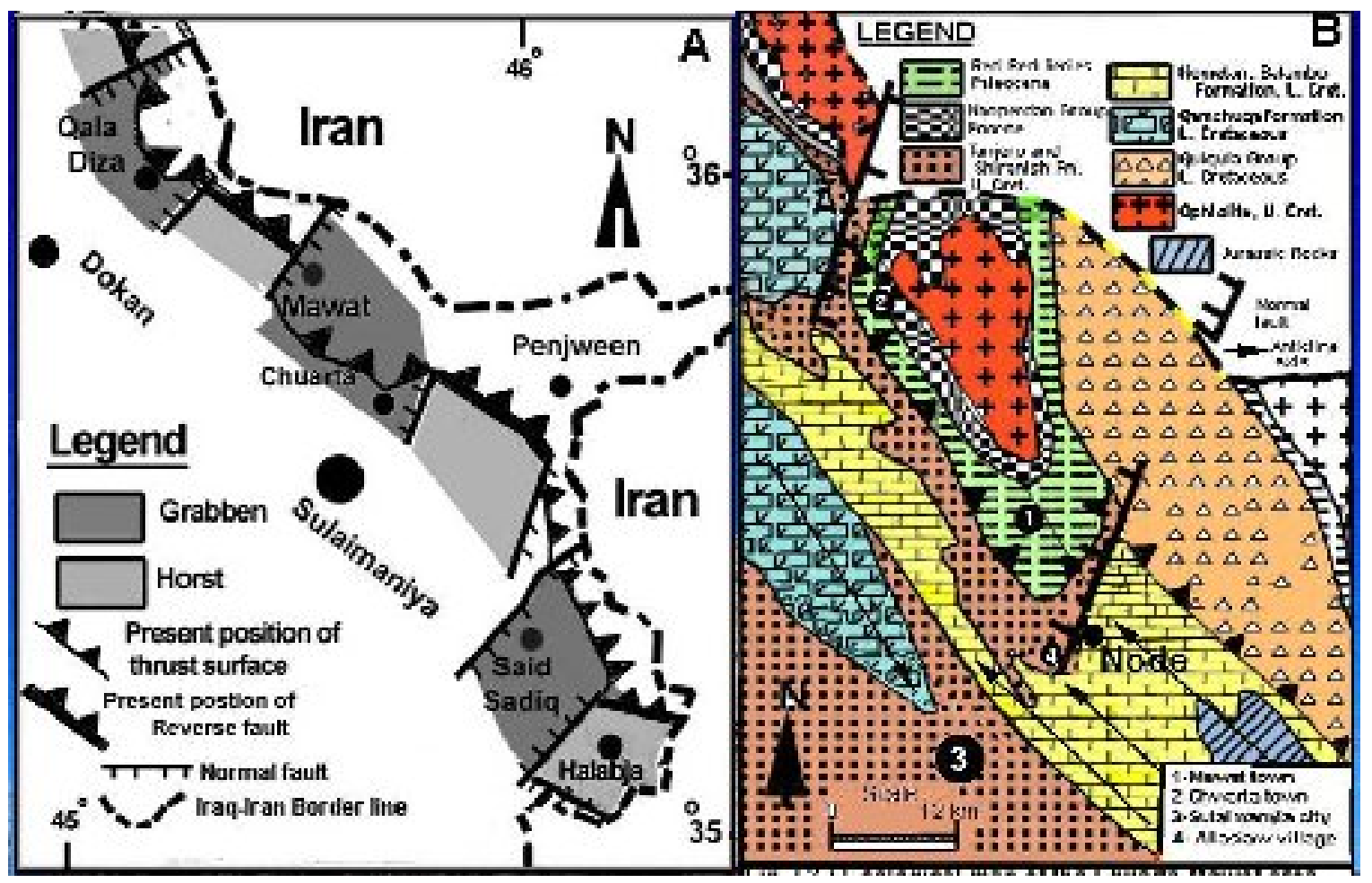

Fig.5: (A) Division of the studied area (thrust and imbricate zones) into several blocks transversally by normal faults. (B) Position of the two normal faults that bound Mawat graben. 


\section{4- Transverse faults}

In addition to the main thrust faults, there are many transverse normal faults that cut across (nearly normal to) the axes of the anticlines and main Zagros Thrust Fault. These faults divide the area into many uplifted and subsided blocks (Fig. 5A).These blocks make horsts and grabens which are bounded by normal faults and their traces, on the surface, die out towards the southwest and are obscured towards northeast by the southeast thrusting of the front of Iranian plate. The erosion has highly modified the topography of these faults but they could be identified in the field. They are difficult to be identified from satellite images and could be indirectly inferred from the large elevation and depressions that bound these faults (Fig.5A).

The most important feature that is associated with blocks is, the Zagros Thrust Fault which makes a reverse faults with horst (light grey blocks of the fig. 5A) and low angle with the grabens (dark blocks of the same figure $5 \mathrm{~A}$ ). The thrust can be seen in several areas such as the Chuwarta-Mawat and Said Sadiq areas, while the reverse faults could be seen in the two areas between Chuwarta-Sadiq and Halabja areas. In these areas the Qulqula Radiolarian Formation (as a thrust front) climbs over Balambo Formation (or Jurassic Rocks) with an angle nearly equal to about 40 degrees. The age of these transverse faults is not known but they appear, from stratigraphy, that most of them are younger than Eocene. The evidence of the two of these faults is discussed in details by Karim (2005a) (Fig. 5B).

\section{5-Drainage discharge direction (sediments transport direction)}

Another kind of lineament is the direction of the drainage discharge (direction of sediments transport) which trends from northeast to northwest. This trend has close relation to the geologic, geomorphologic and tectonic history of the studied area. The first uplift in the extreme northeast of Iraq and its migration towards southwest is the main factor for shaping of this lineament. The chronology of this uplift is controversial and according to many studies it occurred during Eocene (Numan, 1997 and Al-Qayim, 2000). Other studies mentioned the occurrence of uplift at the Campanian, among these (Karim 2004b, Karim and Surdashy, 2005b). According to the last study and that of Al-Barzinjy, 2005) and Karim et al., (2008) the paleoslope and drainage directions were nearly in the same direction from Campanian to Eocene (Fig. 6). The first uplift of the northeastern part of the studied area started near the Iran-Iraq border. Al-Barzinjy, (2005) and Karim et al., (2008) indicated that paleocurrent was towards the south and southwest during Upper Cretaceous, Paleocene and Eocene. The measurements of the paleocurrent of Upper Bakhtiary by imbricated pebbles, in the present study, reveal nearly the same direction of that in the Tanjero Formation and Red Beds Series. The data of paleocurrent as collected from cross bedding and imbricated pebbles are well documented in Karim (2004) and Al-Barzinjy (2005) (for the last two units.)

As connected with sediments transport and drainage discharge, Karim and Surdashy (2006) found four large incised valleys in the sediments of the Maastrichtian filled with boulder and pebble conglomerates (Fig. 4). They mentioned that each valley was associated with low stand delta, submarine fan and channels. During the above mentioned ages the studied area was occupied by large foreland 
basin which was located in front of the advancing head of the Zagros thrust fault (Fig. 6). Therefore the discharge direction, in the past and present, is closely related to the tectonic uplift of the area now called Zagros Fold-Thrust belt and the foreland basin in front of it. It is generally accepted, that the main streams such as Dilla, Little and Great Zab Rivers are flowing on the large transverse faults that cut both the basement and sedimentary strata. Therefore, the drainage discharge is an important type of lineaments which is related to uplifting and fracturing developed by collision of the Arabian and Iranian plates.

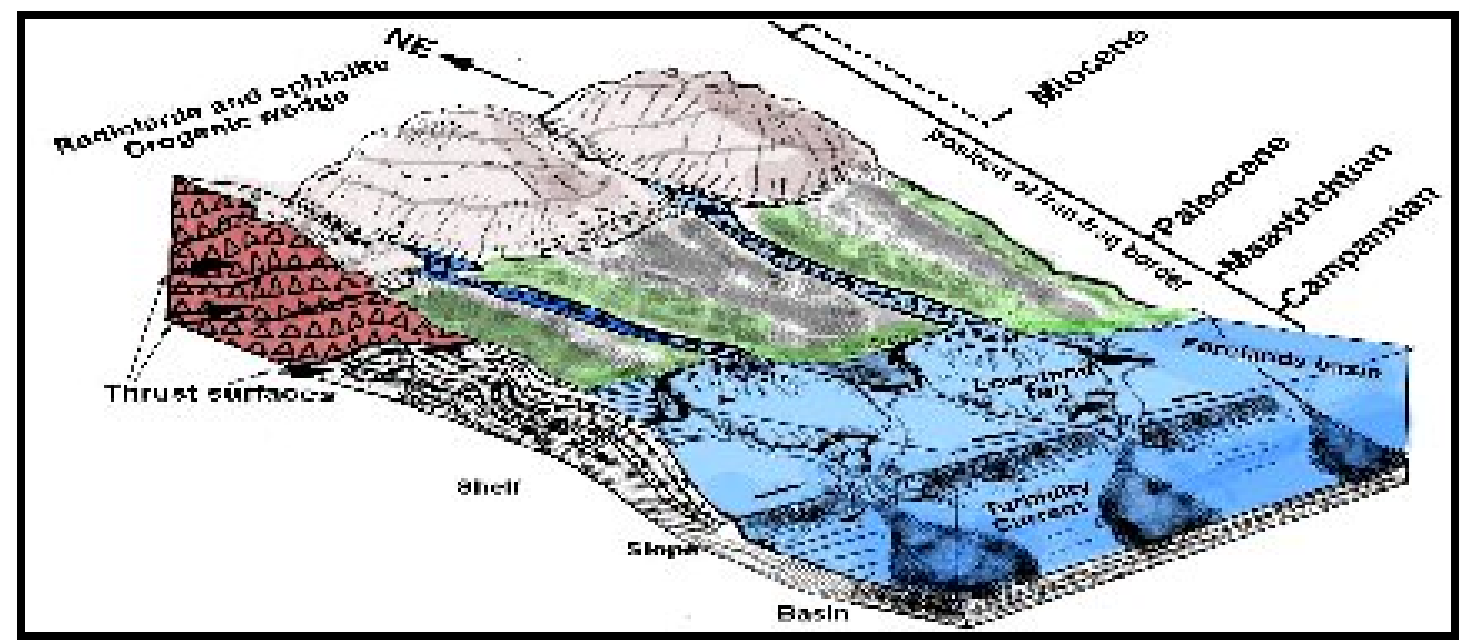

Fig.6: Tectonic and paleogeographic models for the sediment transport. It shows the location of the shoreline (Location of deposition of the studied conglomerates) as respected to present location of Iran- Iraq border (During Maastrichtian, the shoreline was nearly coinciding with the present border).

\section{6-Direction of the maximum facies change}

Other types of the lineaments are the direction of the maximum facies change that can be detected from facies maps and satellite images as well as from field observation across the strike of strata. In the field, the coarse grain clastic sediments (facies) of Upper Cretaceous, Tertiary to Recent change to fine grain ones towards southwest. The sedimentary facies are arranged in down lapped fashion on each other towards the southwest from shallow to deep facies. Karim (2004) described facies changes of Maastrichtian from boulder conglomerates to marly limestone passing through sandstone and shale. The trend of the facies change is toward southwest beginning from conglomerate, from extreme northwest (near Chuwarta and Mawat), to marly limestone at the southwest (near Chamchamal town). This type of facies change, is continuous and migrates towards the southwest and can be seen from satellite image across the limps of anticlines. The facies change can be applied to metamorphic facies also. They show variations from schist to slate and passing through phyllite from inside Iran to Iraq then changes to fresh sedimentary rocks at $20 \mathrm{~km}$ inside Iraq. The metamorphic facies are related to depth of metamorphism and dynamic of the plate collision. 


\section{RECORDED CONGLOMERATE IN THE STUDIED AREA}

The facies change is clearer in the case of clastics dominating successions that start from conglomerate in the coastal area and ends up by shale or limestone in the offshore or (distal area) (Pettijhon, 1975, Blatt et al., 1980 and Tucker, 1990). These two end members pass through intermediate facies such as sandstones and siltstones. The change of position of the conglomerates with time is a direct reflection of the tectonic activities in the studied area and is represented by juxtaposition of fine clastics by conglomerate in the foreland basin towards southwest. This is attributed to rejuvenated erosion by continuous uplift and advance of Iranian plate towards the southwest. Many thick conglomerate successions are found by the present authors and other workers (AlBarzinjy, 2005, Karim, 2004) which have the depositional axes parallel to the axis of main Zagros thrust fault (Fig. 6). Each conglomerate successions could be assigned to a certain age and location. The paleocurrent and tectonic migration directions are indicated by Imbricated pebbles and cross bedding. The migration has resulted either from migration of the thrust front or southwest moving of the folding or deformation front. This southwest migration of the conglomerate depocenter shows more than $60 \mathrm{~km}$ of movement from the Upper Cretaceous to Pliocene time (Fig. 5 and 6). These conglomerates are as follows, arranged from older to younger:

\section{1-Lower Maastrichtian conglomerate}

This is a very abundant conglomerate and located at the base of the Tanjero Formation The maximum thickness is $500 \mathrm{~m}$ and exposed at Chuarta, Mawat, and Qandil areas near the border of Iran and was studied by Karim (2004) and Karim and Surdashy (2005). These workers put this conglomerate at the lower part of Tanjero Formation by correlation (stratigraphically and lithologically) with $400 \mathrm{~m}$ of sandstone and shale beds south of Sulaimanyia City and Dokan area (Fig. 8). The conglomerate thickness is at maximum in the location of the paleo- incised valleys. It is possible that this conglomerate is an indicator of the first appearance of some of the present lineaments such as the ophoilite and thrust fault.

\section{2-Upper Maastrichtian-Eocene conglomerate}

The strata of Late Maastrichtian to Eocene contain several lensoidal conglomerate beds and successions. They include the upper part of Tanjero Formation, Kolosh Formation and Red Bed Series in addition to Sinjar and Gercus Formations. Their thicknesses are variable and change from proximal to distal areas and range from $20 \mathrm{~cm}$ to $1000 \mathrm{~m}$. Geographically these conglomerates are not found in all places as they appear in some places and disappear in others. In north of Darbandikan town, they reach about $(60 \mathrm{~m})$ and belong to Gercus Formation while toward Haibat Sultan Mountain they are intermittently exposed as thin lenses. Al-Barzinjy (2005) correlated this conglomerate (in Darbandikan area) with the unit three (1000m thick) of the Red Bed Series and indicated the southwest paleocurrent direction (Fig.9 and 10A). Some of these conglomerates are deposited in the coastal area of the foreland basin while others are transported to distal area by debris flow. These conglomerates are discussed in detailed by Buday (1980), Karim (2004) and Al-Barzinjy (2005). 


\section{3-Lower Oligocene conglomerate}

This conglomerate consists of (2-10m) of well developed conglomerate and located between Pila Spi and Fat ha Formation at the boundary between Low and High Folded Zones. It is indicates as (conglomerate) no.3 on the map (Fig. 7) and on the stratigraphic column (Fig. 8).

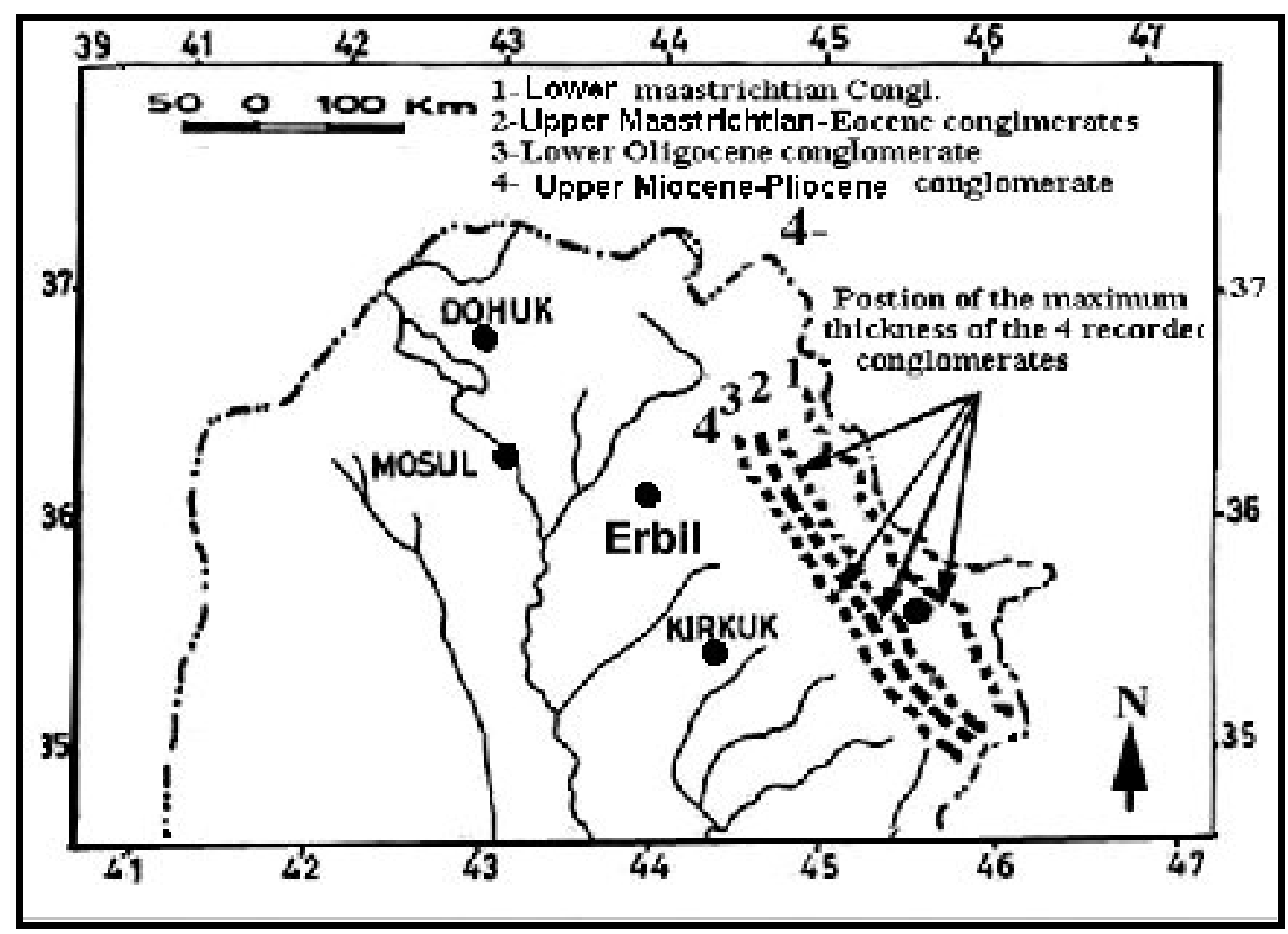

Fig.7: Present location of the maximum thickness of the recorded conglomerate succession in the studied area from Lower Maastrichtian to Pliocene

\section{4-Upper Miocene- Pliocene conglomerate}

This conglomerate succession is the conglomerate of no.4 in the (Fig.7), consists of very thick pile of pebbles, pebbly sandstone and interbedded with red claystone and erosional surfaces. This pile includes Mukdadyia and Bai Hassan (Lower and Upper Bakhtiary) Formations and studied by Bellen et al., (1959) and Buday (1980). The thickness of this conglomerate is more than $1500 \mathrm{~m}$ and is located mainly in the Low folded Zones. The paleocurrent of this conglomerate is towards southwest (Fig. 10B). 


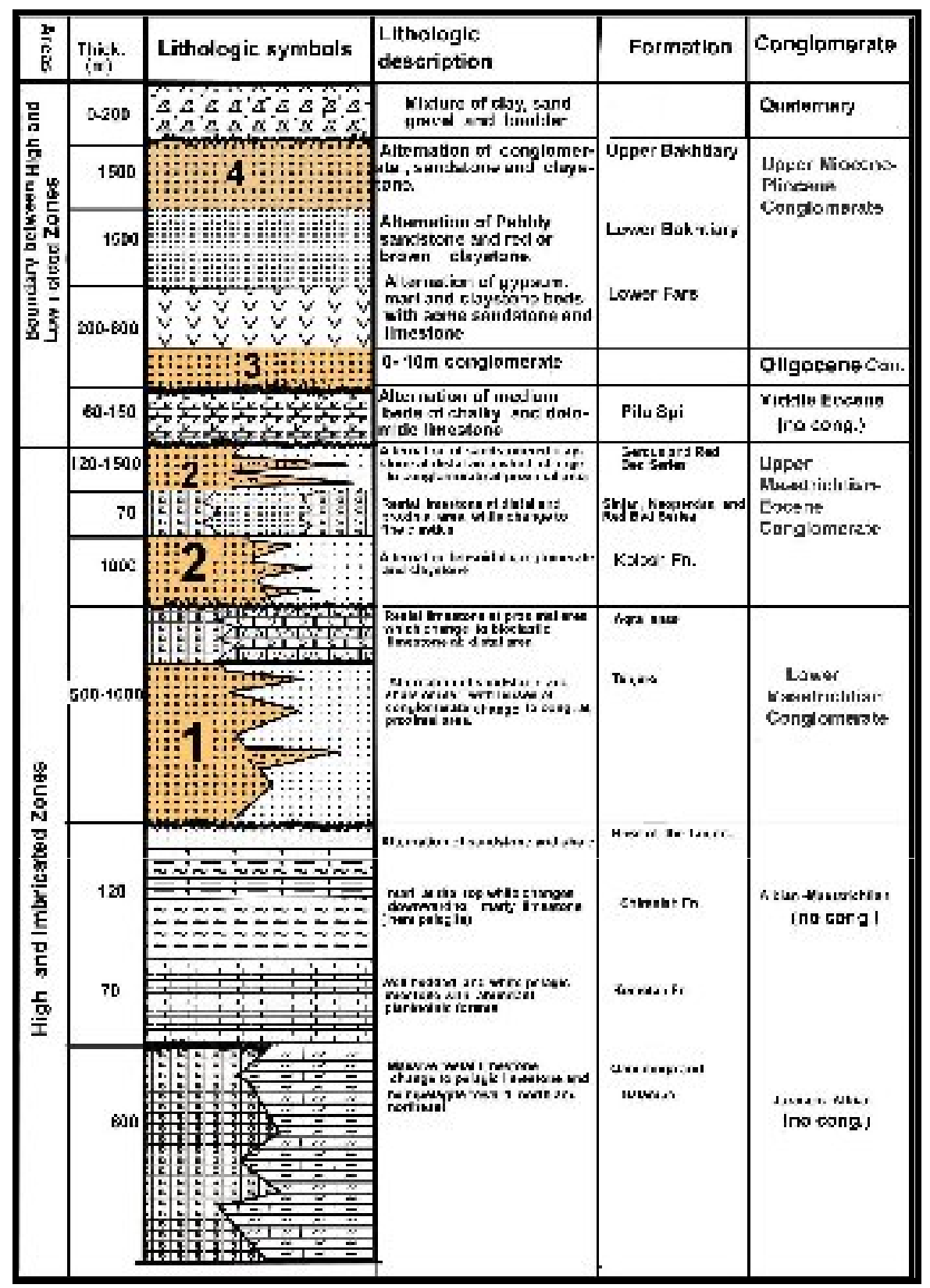

Fig. 8: Stratigraphic column of the exposed units of the studied area showing the position of the studied conglomerates.

\section{COMPUTOR PLOTTING OF THE DATA}

Paleocurrent indication is important for knowing the paleoshore line, sediment transport direction, direction of the elongation of the submarine fans, incised valleys and direction of the facies changes. Therefore imbricated pebble analysis is important for the history and elongation of the lineaments. In the present study, the outcrops of the conglomerate of Gercus and Upper Bakhtiary formations have been surveyed (for Tanjero Formation and Red Bed Series see Karim, 2004 and Al-Barzinjy, 2005). For rose diagram plotting, the azimuth of the direction of the plunging of the pebbles are taken by compass and tabulated. The plunging direction is reversed 180 degrees to change the plunge to the direction of the imbrication (direction of paleocurrent as seen in table1). The data of each station are entered to the Rockwork software as one column. 
Then the unidirectional option is activated in the program when the activated rose diagram gives the paleocurrent direction as shown in the figure 11 .

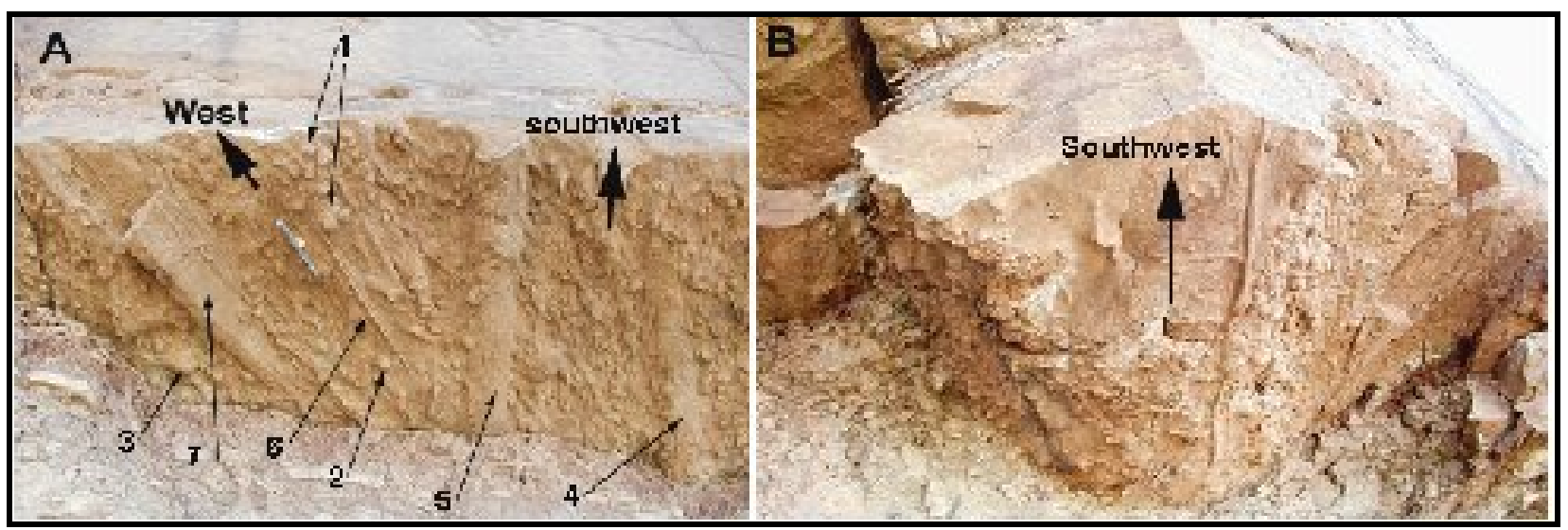

Fig. 9: A)Underside of a thick pebbly sandstone bed (1.5m wide) of the unit one of Red Bed Series showing paleocurrent direction toward southwest during the Paleocene. Flute casts $(1,2$, and 3$)$, small and large groove casts $(4,5)$ and striation casts $(6,7)$. B) Small eroded channel $(30 \mathrm{~cm}$ wide) showing groove casts in the red claystone of the same unit in the same bed (Al-Barzinjy, 2005).

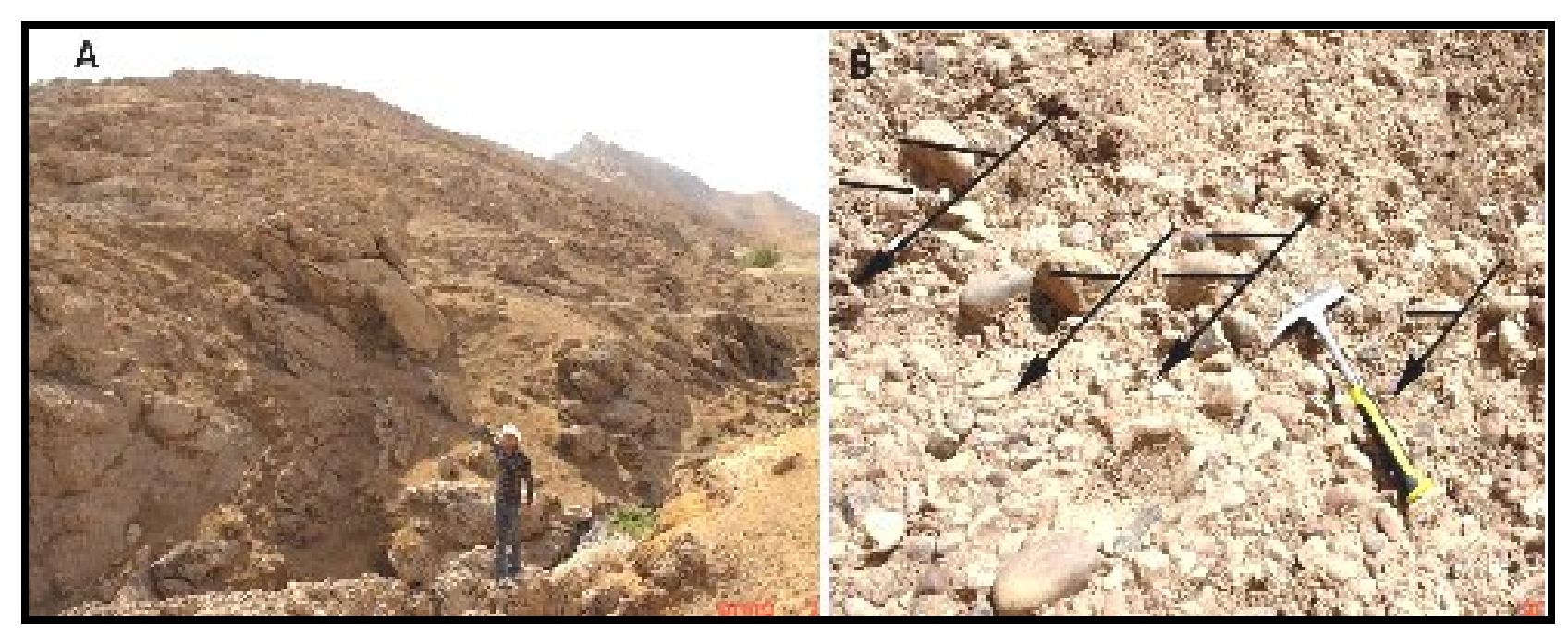

Fig.10: (A) Eocene (Gercus Formation) conglomerate about 60m thick forming a mountain clalled "Barda Asin" at northwest of Darbandikhan town, southwest of Zarayen town. B) Upper Bakhtiary Formation (Pliocene) conglomerate shows southwest paleocurrent direction. The arrows indicate paleocurrent direction and bedding surfaces while small inclined lines indicate directions of pebble imbrications. 
Table1: Direction of the imbrication of gravels and boulders in the conglomerate of Formation and Upper Bakhtiary Formations.

\begin{tabular}{|c|c|c|c|c|c|c|c|}
\hline \multicolumn{4}{|c|}{$\begin{array}{l}\text { Eocene Conglomerate (Gercus } \\
\text { Formation) }\end{array}$} & \multicolumn{4}{|c|}{ Upper Miocene-Pliocene (Upper Bakhtiary Fn.) } \\
\hline \multicolumn{2}{|c|}{$\begin{array}{l}\text { Barda Asin Mountain } \\
\text { South of Zarayeen town }\end{array}$} & \multicolumn{2}{|c|}{ Sartak Bamo } & \multicolumn{2}{|c|}{$\begin{array}{l}\text { South of Darbandikhan } \\
\text { Town }\end{array}$} & \multicolumn{2}{|c|}{\begin{tabular}{|l|}
$\begin{array}{l}\text { South of Chamchama } \\
\text { Town }\end{array}$ \\
\end{tabular}} \\
\hline 220 & 170 & 181 & 141 & 291 & 185 & 234 & 244 \\
\hline 231 & 193 & 145 & 166 & 360 & 171 & 332 & 200 \\
\hline 68 & 205 & 285 & 228 & 233 & 231 & 178 & 281 \\
\hline 276 & 230 & 200 & 251 & 257 & 248 & 356 & 230 \\
\hline 254 & 211 & 123 & 185 & 197 & 313 & 259 & 168 \\
\hline 238 & 261 & 287 & 239 & 240 & 172 & 203 & 282 \\
\hline 245 & 178 & 142 & 260 & 187 & 189 & 170 & 145 \\
\hline 120 & 305 & 202 & 191 & 244 & 231 & 267 & 232 \\
\hline 190 & 270 & 235 & 298 & 197 & 197 & 185 & 239 \\
\hline 187 & 23 & 222 & 198 & 210 & 131 & 45 & 231 \\
\hline 253 & 249 & 278 & 189 & 236 & 170 & 122 & 238 \\
\hline 92 & 111 & 311 & 131 & 142 & 251 & 346 & 288 \\
\hline 274 & 270 & 340 & 270 & 270 & 247 & 247 & 300 \\
\hline 170 & 256 & 285 & 170 & 135 & 214 & 283 & 273 \\
\hline 251 & 237 & 272 & 131 & 128 & 165 & 235 & 282 \\
\hline 170 & 248 & 255 & 196 & 190 & 199 & 200 & 222 \\
\hline 188 & 244 & 261 & 178 & 183 & 197 & 244 & 261 \\
\hline 202 & 213 & 213 & 186 & 174 & 155 & 159 & 230 \\
\hline 283 & 350 & 156 & 175 & 175 & 177 & 123 & 306 \\
\hline 245 & 257 & 170 & 211 & 230 & 260 & 340 & 122 \\
\hline 231 & 256 & 254 & 232 & 212 & 224 & 360 & 267 \\
\hline 270 & 345 & 186 & 131 & 233 & 220 & 248 & 334 \\
\hline 350 & 150 & 322 & 154 & 256 & 215 & 205 & 124 \\
\hline 246 & 200 & 232 & 189 & 195 & 112 & 212 & 267 \\
\hline 199 & 198 & 187 & 242 & 277 & 154 & 305 & 189 \\
\hline 206 & 207 & 193 & 78 & 241 & 181 & 314 & 188 \\
\hline 241 & 218 & 203 & 186 & 176 & 223 & 256 & 199 \\
\hline 295 & 215 & 216 & 175 & 199 & 223 & 279 & 109 \\
\hline 257 & 241 & 230 & 194 & 194 & 210 & 300 & 230 \\
\hline 211 & 277 & 143 & 222 & 226 & 230 & 33 & 143 \\
\hline 185 & 269 & 266 & 200 & 220 & 325 & 267 & 266 \\
\hline 233 & 217 & 177 & 220 & 163 & 150 & 267 & 177 \\
\hline 241 & 88 & 199 & 166 & 215 & 209 & 289 & 199 \\
\hline 206 & 254 & 190 & 280 & 261 & 244 & 236 & 190 \\
\hline 247 & 306 & 255 & 184 & 236 & 176 & 233 & 255 \\
\hline 264 & 340 & 160 & 309 & 344 & 254 & 278 & 322 \\
\hline 356 & 289 & 233 & 290 & 266 & 258 & 190 & 108 \\
\hline 290 & 301 & 268 & 68 & 206 & 150 & 45 & 268 \\
\hline 307 & 177 & 111 & 304 & & 190 & 309 & 187 \\
\hline
\end{tabular}




\section{LINEAMENT OF THE NORTHERN IRAQ}

It is possible that the same or most of the lineaments occurring in the northern Iraq, including North Thrust Zone, have nearly the same historical development, but with different direction and all are diverted anticlockwise by about 40 degrees as compared to the northeastern Iraq (Zagros Fold-Thrust belt). The anticlines and thrust front are trending nearly east-west. It is possible that the drainage, facies migration direction was towards south instead of the southwest. The main factor for diversion of the trend of the lineament is the collision of Arabian and Turkish plate which generated the Tauros Mountain Belt. Al-Brifkani (2008) has mentioned that most lineaments, in this area, are trending towards north-south and east- west.

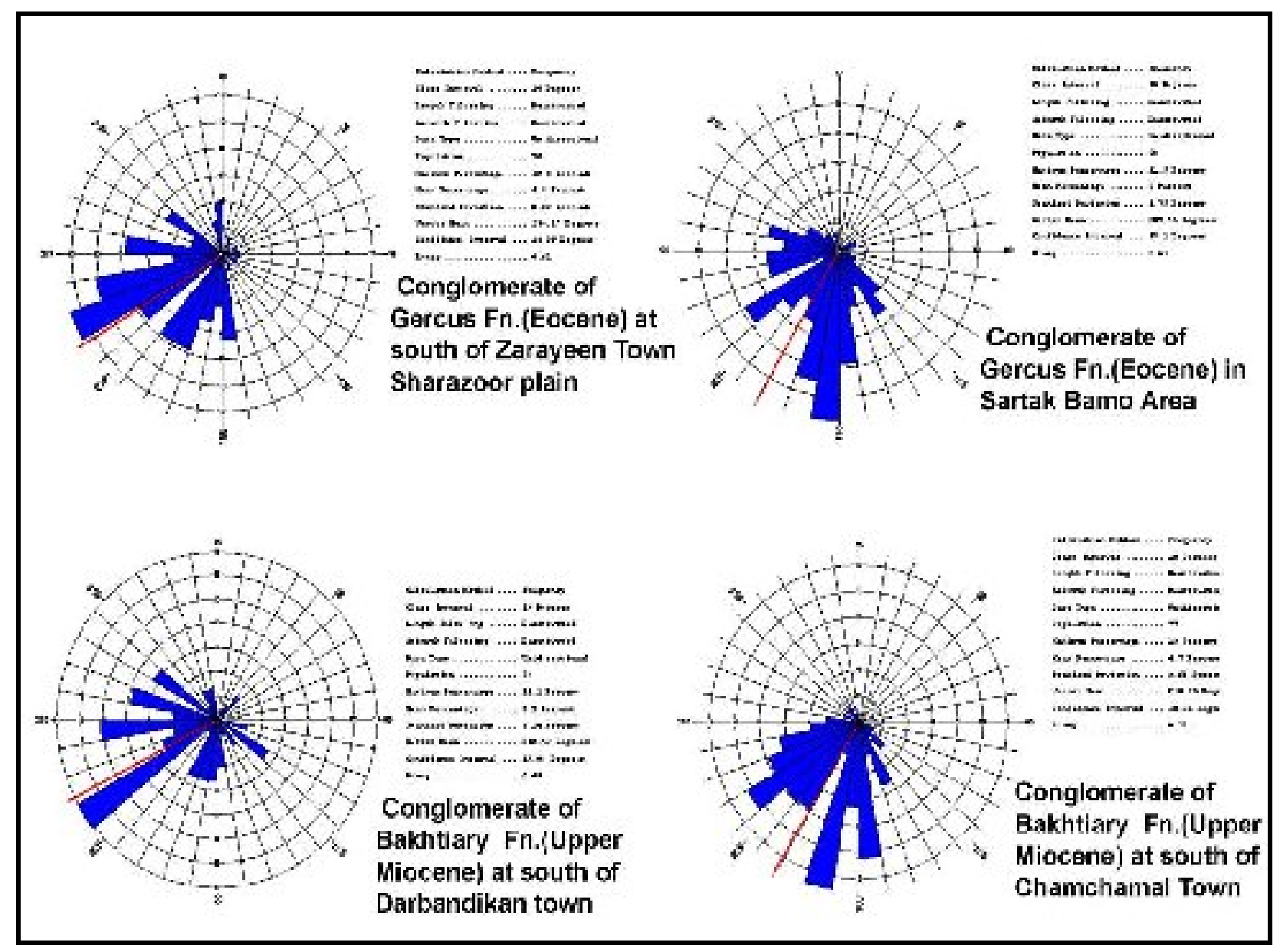

Fig.11: Rose diagrams show paleocurrent direction (sediment transport direction) as indicated by imbricated pebbles of conglomerate of Eocene and Pliocene.

This paper has the following conclusions:

1- The most important main lineaments are axes of anticlines; transverse faults; line of distribution of ophiolites; drainage discharge direction and maximum thickness of conglomerates.

2- It is found that the trends and history of these lineaments are closely related to the development of the Zagros Fold -Thrust Belt. 
3- The first appearance of ophiolites (as gravel and boulder in clastic sediment) was at Lower Maastrichtian.

4- The first appearance of anticlines is Campanian age, but it is Eocene and Upper Miocene in the Thrust, High and Low Folded Zones respectively.

5- The first appearance of southwest direction of drainage (sediment transport) is aged Upper Cretaceous as indicated by incised valleys and imbricated pebbles.

6- The trends and positions of conglomerates could be considered as a lineament with a southwest trend of migration for about 50km from Upper Cretaceous till the Pliocene.

\section{Acknowledgments}

The authors express their best thanks to the Swedish International Development Cooperation Agency (sida) for their financial supports covering the fieldworks of this paper.

\section{REFERENCES}

Abdel-Kireem, M.R., 1986. Planktonic Foraminifera and Stratigraphy of the Tanjero Formation (Maastrichtian), Northeastern Iraq. Micropaleontology, Vol. 32, No.3, pp. 215-231.

Al-Barzinjy, S.T.M., 2005. Stratigraphy and Basin Analysis of Red Bed Series from Northeastern Iraq-Kurdistan Region. Unpublished Ph.D. Thesis, University of Sulaimani, 159p.

Al-Brifkani, M.J.N., 2008. Structural and Tectonic Analysis of the Northern Thrust Zone (East Khabour River). Unpublished Ph.D. Thesis, University of Mosul, 160P.

Al-Kadhimi F., Sissakian V., and Duraid, 1996. Tectonic Map of Iraq. GEOSURV, Baghdad.

Al-Mehaidi, H.M., 1975. Tertiary Nappe in Mawat Range, N.E Iraq, Jour. Geol. Soc. Iraq, Vol. 8, pp. 31-44.

Al-Qayim, B., 2000. Sedimentation and Tectonic Environment of the Suwais Red Beds, NE-Margin of the Arabian plate $-5^{\text {th }}$ International on the Geology of the Arab World, Egypt. Abstract Book, 112p.

Aswad, K.J., 1999. Arc-Continental Collision in Northern Iraq as Evidenced by the Mawat and Penjween Ophiolite Complexes. Raf. Jour. Sci. Vol.10. No. 1., pp.51-61.

Bolton, C.M.G., 1958.The Geology of Ranya Area. Site Inv. Co. UnpublIshed. Report, SOM Library, Baghdad.

Aswad, K.J. and Elias, E.M., 1988. Petrogenesis and Geochemistry and Metamorphism of Spilitized Subvolcanic Rocks, Mawat Ophiolite Complexes. NE-Iraq. Ofioliti, 13, pp. 95-109.

Buday, T., 1980. Regional Geology of Iraq, Vol. 1 Stratigraphy, I.I.M Kassab and S.Z. Jassim (Eds) D.G. Geol. Surv. Min. Invest. Publ. 445p. 
Buday, T., and Jassim, S.Z., 1987. The Regional geology of Iraq: Tectonism Magmatism, and Metamorphism. I.I. Kassab and M.J. Abbas ( Eds ), Baghdad, 445 p.

Bellen, R.C. Van., Dunnington, H.V.; Wetzel R. and Morton, D., 1959. Lexique Stratigraphique, Interntional. Asie, Iraq. Vol. 3,c. 10a, 333 p.

Dunnington, H. V., 1958. Generation, Migration and Dissipation of Oil in Northern Iraq. In : Arabian Gulf, Geology and Productivity. AAPG Foreign Reprint Series No. 2.

Jassim, S.Z. and Al-Hassan, 1977. Petrography and Origin of the Mawat and Penjwin Igneous Complexes. Jour. Geol. Soc. Iraq. Special Issue on 4th Iraqi Geological Conferences, Baghdad, 1976.

Karim, K.H., 2004a. Some Sedimentary and Structural Evidence of Possible Graben in Chuarta-Mawat Area, Sulaimanyia Area, NE-Iraq. Iraqi Journal of Earth Sciences, Vol. 5, No. 2, pp.9-18.

Karim, K.H., 2004b. Basin Analysis of Tanjero Formation in Sulaimaniya Area, NE-Iraq. Unpublished Ph.D. Thesis, University of Sulaimani, 135p.

Karim, K.H. and Surdashy, A.M., 2005a. Paleocurrent Analysis of Upper Cretaceous Foreland Basin: a Case Study for Tanjero Formation in Sulaimanyia area, NEIraq, Iraqi Journal of Earth Sciences, Mosul University, Vol. 5, No. 1, pp. 30-44.

Karim, K.H. and Surdashy, A.M., 2005b. Tectonic and Depositional History of Upper Cretaceous Tanjero Formation in Sulaimaniya Area NE-Iraq. JZS, Vol.8, No.1.

Karim, K.H. and Surdashy, A.M., 2006. Sequence Stratigraphy of Upper Cretaceous Tanjero Formation in Sulaimanyia Area, NE-Iraq. KAJ, Vol. 4. No. 1.

Karim, K.H., Al-Barzinjy S.T. and Ameen, B.M., 2008. History and Geological Setting of Intermontane in the Zagros Fold-Thrust Belt, Kurdistan Region, NE-Iraq. Iraqi Bulletin of Geology and Mining, GEOSURV, Vol. 4. No. 1. pp. 12-33.

Lawa, F.A., 2004. Sequence Stratigraphic Analysis of the Middle Paleocene -Middle Eocene in the Sulaimani District (Kurdistan Region). Unpublished Ph.D. Thesis, University of Sulaimani.

Numan, N.M.S., 1997. A Plate Tectonic Scenario for the Phanerozoic Succession in Iraq. Iraqi Geological Journal, Vol. 30, No. 2, pp.85-110.

Numan, N.M.S., 2000. Discussion of Dextral Transpression in the Late Cretaceous Continental Collision, Sanandaj-Sirjan Zone, Western Iraq. Journal of Structural Geology, Vol. 22, No.8, pp. 1125-1139.

Numan, N.M.S. and Al-Azzawi, N.K., 2002. Progressive Versus Paroxysmal Alpine Folding in Sinjar Anticline, Northwestern Iraq. Iraqi Journal of Earth Sciences, Vol. 2, No. 2, pp. 59-69.

Omar, A.A., 2006. An Integrated Structural and Tectonic Study of the Bina Bawi-SafinBradost Region. Unpublished Ph.D. Thesis, University of Salahaddin, 230 p. 
Turrini, C., Ravaglia, A. and Perotti, C.R., 2001. Compressional Structures in a Multilayered Mechanical Stratigraphy: Insight from Sandbox Modeling With Three-Dimentioinal Variations in the Basal Geometry and Friction. In: Tectonic Modeling by H. A. Koyi and N. L. Mancktelow. (Editor) Geological Society of America Memoir $193 \mathrm{p}$.

Schreurs, G. Hanni, R. and Vock, P., 2001. Four-Dimensional Analysis of Analog Model: Experts on Transfer Zones in Fold and Thrust Belts. In: Tectonic Modeling by H.A. Koyi and N.L. Mancktelow.(Editor)Geological Society of America Memoir 193p.

Marshak, S., 2004. Salients, Recesses, Arcs, Oroclines, and Syntaxes-A Review of Ideas Concerning the Formation of Map-View Curves in Fold-Thrust Belts, in K.R. Mc Clay, ed., Thrust Tectonics and Hydrocarbon Systems: AAPG Memoir 82, pp. $131-156$. 